\title{
THE VALUE OF FORESTATION IN ABSORBING CARBON DIOXIDE SURROUNDING A COAL FIRED POWER PLANT
}

\author{
V.D. Dang ANd M. Steinberg
}

August 1980

\section{MASTER}

DEPARTMENT OF ENERGY AND ENVIRONMENT

BROOKHAVEN NATIONAL LABORATORY

UPTON, NEW YORK 11973 


\section{DISCLAIMER}

This report was prepared as an account of work sponsored by an agency of the United States Government. Neither the United States Government nor any agency Thereof, nor any of their employees, makes any warranty, express or implied, or assumes any legal liability or responsibility for the accuracy, completeness, or usefulness of any information, apparatus, product, or process disclosed, or represents that its use would not infringe privately owned rights. Reference herein to any specific commercial product, process, or service by trade name, trademark, manufacturer, or otherwise does not necessarily constitute or imply its endorsement, recommendation, or favoring by the United States Government or any agency thereof. The views and opinions of authors expressed herein do not necessarily state or reflect those of the United States Government or any agency thereof. 


\section{DISCLAIMER}

Portions of this document may be illegible in electronic image products. Images are produced from the best available original document. 


\title{
THE VALUE OF FORESTATION IN ABSORBING CARBON DIOXIDE SURROUNDING A COAL FIRED POWER PLANT
}

\author{
V.D. Dang ANd M. Steinberg
}

August 1980

Work Performed for the

DIVISION OF ENVIRONMENTAL CONTROL TECHNOLOGY

UNITED STATES DEPARTMENT OF ENERGY

WASHINGTON, D.C. 20545

\author{
M. STEINBERG, HEAD \\ PROCESS SCIENCES DIVISION
}
DEPARTMENT OF ENERGY AND ENVIRONMENT BROOKHAVEN NATIONAL LABORATORY
ASSOCIATED UNIVERSITIES, INC.

UNDER CONTRACT NO. DE-AC02-76CH00016 WITH THE UNITED STATES DEPARTMENT OF ENERGY

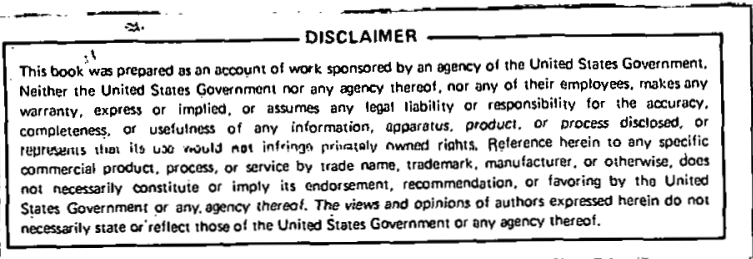




\section{DISCLAIMER}

This repuit was prepared as an accuunt of work sponsored by an agency of the Unired States Government. Neither the United States Government nor any agency thereof, nor any of their employees, nor any of their contractors, subcontractors, or their employees, makes any warranty, express or implied, or assumes any legal liability or responsibility for the accuracy, completeness, or usefulness of any information, apparatus, product, or process disclosed, or represents that its use would not infringe privately owned rights. Reference herein to any specific commercial product, process, or

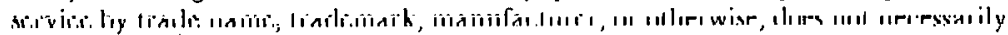
constitute or imply its endorsement, recommendation, or favoring by the United States Government or any agency, contractor or subcontractor thereof. The views and opinions of authors expressed herein do not necessarily state or reflect those of the United States Government or any agency, contractor or subcontractor thereof.

Printed in the United States of America

Available from

National Technical Information Service

U.S. Department of Commerce

5285 Port Royal Road

Springfield, VA 22161

Price: Printed Copy $\$ 5.00$; Microfiche $\$ 3.50$ 


\section{THE VALUE OF FORESTATION IN ABSORBING CARBON DIOXIDE SURROUNDING A COAL FIRED POWER PLANT \\ V. D. Dang and M. Steinberg \\ Process Sciences Division \\ Department of Energy and Environment \\ Brookhaven National Laboratory \\ Upton, New York 11973}

August 1980

\section{Abstract}

The dispersion of carbon dioxide emitted from a $1000 \mathrm{MW}(\mathrm{e})$ coal fired power plant is investigated. Calculated ground level carbon dioxide concentrations as a function of distance from the power plant stack is validated by the results derived from sulfur dioxide dispersion measurements. Forestation is examined as a means for removal and control of atmospheric carbon dioxide at a distance of 5 to $10 \mathrm{~km}$ away from the power plant stack. An equilibrium and a dynamic approach are considered. In the equilibrium case, the increase in concentration of $\mathrm{CO}_{2}$ above background is less than $1 \mathrm{ppm}$ and thus the growth rate of forests is not significantly affected by the concentration change. In the dynamic method, it is estimated that a maximum increase of $15 \%$ in $\mathrm{CO}_{2}$ concentration above background can be obtained in the 5 to $10 \mathrm{~km}$ annular ring at ground level. This incremental $\mathrm{CO}_{2}$ concentration would result in an estimated maximum increase of $15 \%$ in the growth rate of trees located in this

area. For an average temperate zone forest growth rate $\left(7.42 \mathrm{mg} / \mathrm{dm}^{2} \mathrm{hr}\right)$, the overall reduction in forested land area required to remove the equivalent of all of the $\mathrm{CO}_{2}$ from a $1000 \mathrm{MW}(\mathrm{e})$ power plant would be less 
than $3.3 \%$ compared to removing the equivalent amount of $\mathrm{CO}_{2}$ by planting forests remotely from the plant. If faster growing tropical plants or trees having up to 4 times the temperate plant growth rate were used, there would be a maximum savings of $15 \%$ in forested land area compared to a remote planting. This magnitude of reduction in cultivated forest area is insufficient to recomend planting forested areas adjacent to central power stations as a means of controlling $\mathrm{CO}_{2}$ emission. Rather it is suggested to provide sufficient increased regional forested areas on a global scale for the purposes of absorbing the equivalent increase in $\mathrm{CO}_{2}$ emission due to increased fossil fuel use. 
THE VALUE OF FORESTATION IN ABSORBING CARBON DIOXIDE

SURROUNDING A COAL FIRED POWER PLANT

\author{
V. D. Dang and M. Steinberg \\ Process Sciences Division \\ Department of Energy and Environment \\ Brookhaven National Laboratory \\ Upton, New York 11973
}

August 1980

\title{
Introduction
}

Emission of carbon dioxide to the atmosphere by the consumption of fossil fuel in the USA has been reviewed in a recent report [1]. The emitted carbon dioxide interacts with the atmosphere, biosphere, and ocean. The final equilibrium concentration of carbon dioxide in the atmosphere results from about fifty percent of the original emission with the remaining absorbed by the blosphere and the ocean. Estimates for 1985 indicate that of the total carbon dioxide to be emitted to the atmosphere, the concentrated sources, which include power and industrial plants, will amount to $54.2 \%$, while that from diffuse sources which consist mainly of automotive emissions will be $45.8 \%$ [1]. For concentrated sources, carbon dioxide can be removed and recovered by various physical and chemical techniques such as absorption/stripping, adsorption, liquefaction, etc. Another possible technique of controlling atmospheric $\mathrm{CO}_{2}$ is through the photosynthetic process for the production of biomass which includes plants and trees. Forests can be planted to take up $\mathrm{CO}_{2}$ and a recent workshop [3] reports the carbon dioxide exchange- with existing forests. 
The concentration of carbon dioxide in gases emitted from a coal fired power plant stack is about $15 \%$ and is thus a falrly concentrated source. The concentration of atmospheric carbon dioxide around a power plant could increase above background, and forestation in this region could possibly act as a control method for carbon dioxide. Coal fired power plants contribute about $25 \%$ of the total US carbon dioxide emission. Thus investigation of a control technology for carbon dioxide emission surrounding a power plant is a significant and worthwhile effort. In the following, a coal fired plant of $1000 \mathrm{MW}(\mathrm{\theta})$ capacity is used for making a first order estimate of the value that forestation may have in capturing and controliing the atmospheric carbon dioxide surrounding a power plant stack.

Atmospheric $\mathrm{CO}_{2}$ Dispersion

Measurement of $\mathrm{CO}_{2}$ concentration away from a power plant is not as extensive as that for $\mathrm{SO}_{2}$. From physical dispersion phenomena, from power plant stacks, it is possible to draw analogous estimates of the ground level concentration of $\mathrm{CU}_{2}$ from $\mathrm{SU}_{2}$ measurements. Fig. 1 shows experimentally measured ground-level $\mathrm{SO}_{2}$ concentrations at distances away from the stack of the Dickerson power plant in Maryland [4] where $H_{m}$ and $h_{e}$ are the mixing length and the effective stack height, respectively. Correlation of these data has also been performed using the Gaussian plume model with various dispersion coefficients $[4, j]$. Solid curves in Fig. 1 are the correlation using the Brookhaven dispersion coefficients [4]. 
For a $1000 \mathrm{MW}(\mathrm{e})$ coal fired power plant with an electrical power cycle effictency of $35 \%$, carbon dioxide is emitted at a rate of $19.32 \mathrm{x}$ $10^{6} \mathrm{gm} / \mathrm{min}$ or $1.52 \times 10^{4} \mathrm{~m}^{3} / \mathrm{min}$ at $300^{\circ} \mathrm{F}$ and 1 atm at the stack. The carbon dioxide in the flue gases will then be dispersed from the stack. Atmospheric dispersion of pollutants has been extensively investigated. An approximate estimate of the carbon dioxide concentration away from the stack can be obtained from the following equation [6, pp. 366-71]

$$
\mathrm{C}=\frac{2.8 \times 10^{-3}}{\mathrm{ud} \Theta \mathrm{h}} \exp \left(-\frac{2.303 \mathrm{H}^{2}}{\mathrm{~h}^{2}}\right) \mathrm{units} / \mathrm{m}^{3}
$$

where $H$ is the actual stack height, $h$ is the plume rise, $u$ is the wind speed, $d$ is the distance downwind from the stack and $\theta$ is the lateral spread.

A schematic illustration of the dispersing process together with the parameters is shown in Fig. 2. For a stack height of $100 \mathrm{~m}$ and other conditions listed in Table 1 [6, Table VIII], one can then determine the carbon dioxide concentration $\mathrm{C}\left(\right.$ units $\left./ \mathrm{m}^{3}\right)$ at four locations $(0.1,1,10$, and $100 \mathrm{~km}$ ) from the stack. The concentration of carbon dioxide in terms of ppm is then obtained by multiplication of C in Eq. (1) and the carbon dioxide flow rate $1.52 \times 10^{4} \mathrm{~m}^{3} / \mathrm{min}$. The carbon dioxide concentration as a function of distance from the stack is shown in Fig. 3. Experience indicates that the maximum surface $\mathrm{SO}_{2}$ concentrations at ground level usually occurs at 5 to $10 \mathrm{~km}$ away from the source [7] and therefore this region is used for the $\mathrm{CO}_{2}$ investigation. The concentration of carbon 
dioxide at ground level is calculated to be between about 48 and $5.2 \mathrm{ppm}$ above background $(\sim 330 \mathrm{ppm})$ at a distance of 5 to $10 \mathrm{~km}$ away from the stack. It is interesting to note that, the incremental ground leve1 concentration of $\mathrm{CO}_{2}$ above background derived from the experimental results of $\mathrm{SO}_{2}$ measurement [4] is 15 to $18 \mathrm{ppm}$ at a distance of 5 to 10 $\mathrm{km}$ away from the stack which is in the same order of magnitude as calculated.

The planting of trees in an area of increased carbon dioxide concentration surrounding the source may be a useful method for improving the removal of carbon dioxide from the atmosphere. However, many factors can affect the uptake of $\mathrm{CO}_{2}$ by trees and forests. Carbon dioxide exchange between the atmosphere and the trees varies with the season. The carbon dioxide concentration in the atmosphere is lower in summer than in spring, fall, and winter [8]. For trees of a given height (average $18 \mathrm{~m}$ [8]), the atmospheric carbon dioxide concentration varies in altitude from the bottom to the top of the tree. Measurements indicate that $\mathrm{CO}_{2}$ concentration decreases when the altitude above ground increases, except In winter where the $\mathrm{CO}_{2}$ concentration remains fairly constant with alt1tude. The variation of $\mathrm{CO}_{2}$ concentration can change from 325 to $305 \mathrm{ppm}$ at $3 \mathrm{~m}$ to $20 \mathrm{~m}$ above ground level in sumer which has the largest variation of the four seasons. Carbon dioxide is practically constant at a value of $295 \mathrm{ppm}$ at 1:00 pm but it varies between 315 and $305 \mathrm{ppm}$ at differeat alliludas at 9:00 pm [8].

It is known that plants take up $\mathrm{CO}_{2}$ concentration and light intensity as can be seen in Figs. 4 and 5 . Full sunlight avallable for 
photosynthesis is equivalent to an energy flux of $42 \times 10^{4} \mathrm{erg} \mathrm{sec}^{-1}$ $\mathrm{cm}^{-2}$. The photosynthetic rate is practically independent of $\mathrm{CO}_{2}$ concentration over $1000 \mathrm{ppm}$ in the environment. Up to about $500 \mathrm{ppm} \mathrm{CO}_{2}$, the growth rate increases 1 inearly with $\mathrm{CO}_{2}$ concentration. At a $\mathrm{CO}_{2}$ concentration of $378 \mathrm{ppm}$ at $5 \mathrm{~km}$ away from the power plant, as shown in Fig. 3 , It is expected that the photosynthetic rate would increase linearly with carbon dioxide concentration as seen in Figs. 4 and 5 . In other words, the growth rate of trees in a $378 \mathrm{ppm} \mathrm{CO}_{2}$ environment should be about $15 \%$

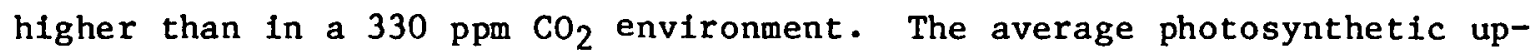
take rate also varies with the type of planting as given in Table 2 [9, pp. 244-5]. The net primary productivity (NPP) of trees also varies among forests as can be seen in Table 3 [2]. In the following discussion, an average forest growth rate of $8.50 \mathrm{mg} / \mathrm{dm}^{2} \mathrm{hr}$ [2] is used for evaluation. Note that $8.50 \mathrm{mg} / \mathrm{dm}^{2} \mathrm{hr}$ is based on a $\sim 378 \mathrm{ppm} \mathrm{CO} 2$ environment which is $15 \%$ higher than for $330 \mathrm{ppm} \mathrm{CO}_{2}$ and a tree growth rate of $7.42 \mathrm{mg} / \mathrm{dm}^{2} \mathrm{hr}$. The latter average forest growth rate corresponds to a forest of oak trees or dogwood.

An estimate of a forest area needed to remove atmospheric carbon dioxide in a region of 5 to $10 \mathrm{~km}$ away from a power plant is quite complex. The fraction of the pollutant in the original source from the stack dispersed over a certain area depends on the wind speed and the characteristic time of the pollutant staying in the atmosphere.

There are two approaches that can be taken when considering forestation of land area for removal of atmospheric carbon dioxide. The 
first approach is an equilibrium one. That is, the $\mathrm{CO}_{2}$ emitted from the power plant has stayed in the atmosphere for a long enough time so that it reaches an equilibrium concentration with the surrounding air. From previous estimates [1], the annual increase in $\mathrm{CO}_{2}$ concentration in the atmosphere due to fossil energy usage is expected to be less than $1 \mathrm{ppm}$. Thus, the increase in forest growth rate due to the effect is negligible. The forestation land area for trees with an average growth rate of $7.42 \mathrm{mg} / \mathrm{dm}^{2} \mathrm{hr}$ required to remove $19.32 \times 10^{6} \mathrm{gm} / \mathrm{min} \mathrm{CO}_{2}$ from a $1000 \mathrm{MW}(\mathrm{e})$ pưwei plaul is $1065 \mathrm{~km}^{2}$. Trees planced in the annular region of $\mathrm{s}$ to 10 km away from the stack w11l cover an annular area of $2.36 \mathrm{~km}^{2}$ and thus should remove only $22 \%$ of the total carbon dioxide emitted from the stack.

The other approach involves a dynamic process where carbon dioxide is removed instantaneously by the trees while taking advantage of a higher carbon dioxide concentration due to the plume dispersion at ground level. Further description of the dispersion process is necessary before estimates of forestation land can be made. Downstream dispersion of a plume from the stack can be stable, neutral or unstable. By means of a gaussian plume dispersion model [1.1], it is possible to determine the average fraction of $\mathrm{CO}_{2}$ emitted from the stack which is dispersed above the annular area of 5 to $10 \mathrm{~km}$ from power plant as listed in Table 4 . For example, the characteristlc time of $\mathrm{SO}_{2}$ in the atmosphere is about 22 hours [13]. For wind speed between 4 to $10 \mathrm{~m} / \mathrm{sec}$ and a characteristic time for $\mathrm{CO}_{2}$ staying in the atmosphere between 0.5 to $1 \mathrm{yr}$, it is found that the average fraction of $\mathrm{CO}_{2}$ from the stack which is dispersed above the annular area of 5 to $10 \mathrm{~km}$ from the power plant lies between 36 and $100 \%$. Because of variations of different parameters such as wind speed, 
light intensity, kinds of trees, etc., it is very difficult to determine

a fixed area for forestation. If young trees with a growth rate of 7.42 $\mathrm{mg} / \mathrm{dm}^{2} \mathrm{hr}$ are planted in an area of $236 \mathrm{~km}^{2}$ to absorb the $\mathrm{CO}_{2}$ emitted from the power plant continuously for 30 years, the trees will grow accordingly. The mass of trees that can be produced due to the output of $\mathrm{CO}_{2}$ from the power plant is $5.3 \times 10^{10} \mathrm{~kg}$ during a thirty year period. If the average final diameter and height of a tree is $0.76 \mathrm{~m}$ and $18.9 \mathrm{~m}$, respectively, there should be a population of approximately 37,462 trees $/ \mathrm{km}^{2}$. It is noted that the density of the Eastern Cottonwoodcan range from 8,000 trees $/ \mathrm{km}^{2}$ to 362,000 trees $/ \mathrm{km}^{2}$ for tree heights in the range of $11 \mathrm{~m}$ to $42 \mathrm{~m}$ and diameters of $0.09 \mathrm{~m}$ to $0.7 \mathrm{~m} \mathrm{[12].} \mathrm{Hence} \mathrm{the}$ estimated forestation density lies within the existing forestry data. As discussed previously, the annular ring area of $236 \mathrm{~km}^{2}$ at a distance of 5 to $10 \mathrm{~km}$ away from the power plant stack can only remove $22 \%$ of the total carbon dioxide emission under equilibrium background $\mathrm{CO}_{2}$ concentrations and an average tree growth rate of $7.42 \mathrm{mg} / \mathrm{dm}^{2} \mathrm{hr}$. Under dynamic conditions, due to the higher concentration of carbon dioxide above this area, a maximum increase in photosynthetic rate of $15 \%$ can be expected. Thus the total amount of forestry area required to remove all of the $\mathrm{CO}_{2}$ from a $1000 \mathrm{MW}(\mathrm{e})$ power plant can be reduced by $3.3 \%$ as shown in the following table: 


\begin{tabular}{cc}
\multicolumn{2}{c}{ Equilibrium } \\
\hline Land & Fraction \\
area, & removed, \\
$\mathrm{km}^{2}$ & $\%$ \\
\hline
\end{tabular}

Dynamic

Land Fraction area, removed, $\mathrm{km}^{2}$ $\%$

Land area and fraction of $\mathrm{CO}_{2}$ removed in 5 to $10 \mathrm{~km}$ annular ring

236

22

236

25.3

Fraction $\mathrm{CO}_{2}$ removed outside annular ring

$\frac{829}{1065} \frac{78}{100} \quad \frac{794}{1030} \cdot \frac{74.7}{100}$

Total 1and area

$35 \mathrm{~km}^{2}$ or $3.3 \%$ of equilibrium

'lotal land savings

\section{$35 \mathrm{~km}$ or $3.3 \%$ of equilibrium}

This small savings in land area is hardly worth the effort for providing a planned forest area immediately surrounding a power plant. However, provision can be made to allot areas in the country for forestation specifically assigned to remove the equivalent mass of $\mathrm{CO}_{2}$ emitted from power plants. For the equilibrlum growth rate assumed, this is equivalent to $1065 \mathrm{~km}^{2}$ per $1000 \mathrm{MW}(\mathrm{e})$. These can be planted anywhere in the country and not necessarily adjacent to a power plant.

There is also the possibility of planting fast growing tropical plants such as sugarcane, sorghım, plgweed, and ounflower that have growth rates more than four times that of $7.42 \mathrm{mg} / \mathrm{dm}^{2} \mathrm{hr}$ assumed above. If these are planted in the annular region of 5 to $10 \mathrm{~km}$ away from the power plant stack and the meteorological conditions are such that almost all the carbon dioxide emitted from the stack is above this region, these plants will tend to remove practically all the carbon dioxide emitted 
from the power plant. However, even in this case the maximum decrease in land area that can be expected due to the dynamic conditions of increased $\mathrm{CO}_{2}$ concentration would be $15 \%$.

Summary and Conclusions

A suggested method of removing $\mathrm{CO}_{2}$ from the atmosphere due to emission from a coal fired power plant is by forestation. Considering a 1000 MW(e) coal fired power plant, the increase in ground level carbon dioxide concentration is estimated to be between 48 and $5.2 \mathrm{ppm}$ above background $(\sim 330 \mathrm{ppm})$ at a distance of 5 to $10 \mathrm{~km}$ away from the power plant. This Increased concentration level is about the same order of magnitude derived from the results of sulfur dioxide measurements. The photosynthetic rate varies with the type of tree in different geographical areas and increases linearly with environmental $\mathrm{CO}_{2}$ concentration up to $500 \mathrm{ppm}$. It is thus expected that a maximum increase of $15 \%$ in tree growth rate would result in the annular region of 5 to $10 \mathrm{~km}$ away from the plant due to increased ground level concentration of $\mathrm{CO}_{2}$.

An equilibrium and a dynamic method for determining planting area"of. forests are compared. A $1000 \mathrm{MW}(\mathrm{e})$ power plant releases $19.32 \times 10^{6}$ $\mathrm{g} / \mathrm{min} \mathrm{CO}_{2}$. The area of trees required with an average cultivated temperate zone growth rate of $7.42 \mathrm{mg} / \mathrm{km}^{2} \mathrm{hr}$ to remove this emission rate is $1065 \mathrm{~km}^{2}$. If trees of this growth rate are in an area of $236 \mathrm{~km}^{2}$, a 5 to $10 \mathrm{~km}$ annular ring, only. $22 \%$ of the total carbon dioxide emitted from the stack will be removed by the forests. It is thus necessary to provide ariother $829 \mathrm{~km}^{2}$ to remove the remaining $78 \%$ of the $\mathrm{CO}_{2}$ emitted. 
Because of the increased photosynthetic rate due to increased ground level concentration mentioned above, the forestation area required for the dynamic case may be $15 \%$ less than that of the equilibrium case. This would result in a net reduction of $3.3 \%$ in land area to remove all of the $\mathrm{CO}_{2}$ emitted from a $1000 \mathrm{MW}(\mathrm{e})$ plant. It is interesting to note that depending on meteorological conditions, the fraction of $\mathrm{CO}_{2}$ absorbed by tree growth which originates from the power plant can vary widely, typically ranging from 36 to $100 \%$. For a thirly year 11 fe power plant, young treco with growth rate of $7.42 \mathrm{mg} / \mathrm{dm}^{2} \mathrm{hr}$ can grow steadily to $18.9 \mathrm{~m}$ tall and $0.76 \mathrm{~m}$ diameter in an area of $236 \mathrm{~km}^{2}$ by ahsorption of $\mathrm{CO}_{2}$ emisaion. The total mass of tree produced is $5.3 \times 10^{10} \mathrm{~kg}$ and the tree density is 37,462 trees $/ \mathrm{km}^{2}$. In comparison with existing forest data the density of the Eastern Cottonwood can range from 8000 trees $/ \mathrm{km}^{2}$ to $3.62 \times 10^{5}$ trees $/ \mathrm{km}^{2}$ at a helght of $11 \mathrm{~m}$ to $42 \mathrm{~m}$ and a diameter of $0.09 \mathrm{~m}$ to $0.7 \mathrm{~m}$, so that this kind of forest planning seems to be reasonable.

Fast growing plants such as sugarcane, sorghum, pigweed and sunflower that have growth rates more than four times the dogwood or oak Lrees, $1.42 \mathrm{mg} / \mathrm{dm}^{2}$, are planted in the annular region of 5 to $10 \mathrm{~km}$ away from the power plant stack would reduce the land requirement accordingly. However, the maximum decrease in forested land area requiren would be no more than $15 \%$.

The general conclusion of this paper is that the increased growth rate and cunsequene reduction in torested land area that can be expected from increased concentration of $\mathrm{CO}_{2}$ in the atmosphere surrounding a large power plant is insufficient to justify the provision of space for 
planting trees adjacent to the power plant as a means of $\mathrm{CO}_{2}$ control. Rather; it is suggested that land area in suitable regions of the country be provided to remove the equivalent amount of $\mathrm{CO}_{2}$ emitted from power plants. On a global scale, increased areas for tropical biomass growth such as rain forests in the tropical zone to absorb the increasing emission of fossil fuel both from central and diffuse sources may be a feasible global control technique. 


\section{REFERENCES}

1. V. D. Dang and M. Steinberg. Emission of $\mathrm{CO}_{2}$ to the Atmosphere Due to U.S.A. Fossil Fuel Consumption. Brookhaven National Laboratory Report BNL-51238 (June 1980).

2. H. Lieth. Vegatation and $\mathrm{CO}_{2}$ Changes in Carbon Dixode, Climate and Society, ed. J. Willlams, Pergamon Press, pgs. 103-9 (1978).

3. T. V. Amentano and J. Hett, ed. "The Role of Temperate Zone Forests in the World Carbon Cycle". CONF-7903105, UC-11, February, 1980.

4. J. C. Weil and A. F. Jepsen. Evaluation of the Gaussian Plume Model at the Dickerson Power plant. Atmospheric Environment 11, 901, 1977.

5. J. D. Weil. Applicability of Stability Classification Schemes and Assoclated Parameters to Dispersion of Tall Stack Plumes in Maryland. Atmospheric Environment 13, 819, 1979.

6. F. Pasquil1. Atmospheric Diffusion. Halstead Press, 1974.

7. S. B. Carpenter, T. L. Montgomery, J. M. Leavitt, W. C. Colbaugh, and F. W. Thomas. Principal Plume Dispersion Models: TVA Power Plant. J. Air Pollution Control Assoc. 21, 491, 1971.

8. H. E. Garrett, G. S. Cox, and J. E. Roberts. Spatial and Temporal Variations in Carbon Dioxide Concentrations in an Oak-Hickory Forest Ravine. Forest Science, 24, 180, 1978.

9. I. Zelitch. Photosynthesis, Photorespiration and Plant Productivity. Academic Press, 1971.

10. P. Gaastra. Photosynthesis of Crop Plants as Influenced by Light, Carbon Dioxide, Temperature, and Stomatal Diffusion Resistance. Mededel Landbouwhogeschool Wageninger 59, 1, 1959.

11. F. M. Frenkie1. Turbulent Diffusion: Mean Concentration D1stribution in a Flow Field of Homogeneous Turbulence. Advances in Applied Mechanics, edited by R. Von Mises and T. Von Karman, Vol. III, Academic Press, New York, pgs. 61-107, 1953.

12. R. D. Forbes. Forestry Handbook. The Ronald Press Co., NY, NY, 1961, p. 32 .

13. J. A. Fay and J. J. Rosengweig. An Analytical Diffusion Model for Long Distance Transport of Air Pollutants. Atmospheric Environment $14,355,1980$. 
Table 1

Calculation of the Distribution of Concentration from a Point Source of strength 1 'unit'/min [6, Table VIII]

\begin{tabular}{lccrc}
\hline Distance d (km) & 0.1 & 1 & 10 & 100 \\
Effective value of $\mathrm{h}(\mathrm{m})$ & 20 & 170 & 2000 & 2000 \\
Lateral spread $0(\mathrm{deg})$ & 120 & 93 & 67 & 40 \\
Effective value of u (m/sec) & 4 & 4 & 6 & 6 \\
C(units $\left./ \mathrm{m}^{3}\right)$ & $2.89 \times 10^{-31}$ & $2 \times 10^{-8}$ & $3.46 \times 10^{-10}$ & $5.8 \times 10^{-11}$ \\
\hline
\end{tabular}


Table 2A

Typical Rates of Net Photosynthesis in Single Leaves of Various Species at High Illuminance and $300 \mathrm{ppm}$ of $\mathrm{CO}_{2}$ in $\mathrm{Alr}$

$[9, \mathrm{pp} \cdot 244-5]$

\begin{tabular}{|c|c|}
\hline Species & $\begin{array}{l}\text { Net photosynthesis, } \\
\text { mg } \mathrm{CO}_{2} \mathrm{dm}^{-2} \mathrm{hr}^{-1}\end{array}$ \\
\hline Maize & $46-63$ \\
\hline Sugarcane & $42-49$ \\
\hline Sorghum & 55 \\
\hline Bermuda grass, Cyandon dactylon & $35-43$ \\
\hline Pigweed, Amaranthus edulis & $\begin{array}{c}58 \\
37-44\end{array}$ \\
\hline $\begin{array}{l}\text { Suntlower } \\
\text { Cattail, Typha latifolla }\end{array}$ & $44-69$ \\
\hline Tobacco & $16-21$ \\
\hline Sugar beet & $24-28$ \\
\hline Orchard grass & $13-24$ \\
\hline Wheat & $17-31$ \\
\hline Bean. & $12-17$ \\
\hline Dak & 10 \\
\hline Maple & 6 \\
\hline Dogwood, Cornus Florida & 7 \\
\hline
\end{tabular}

Table $2 B$

Variation of Net Photosynthesis of Single Leaves within a Species at High Illuminance and $300 \mathrm{ppm}$ of $\mathrm{CO}_{2}$ in Air

[9, nes. 244-5]

\begin{tabular}{lll}
\hline Species & Range of net photosynthesis \\
$\left(\mathrm{mg} \mathrm{CO}_{2} \mathrm{dm}^{-2} \mathrm{hr}^{-1}\right)$
\end{tabular}

$\begin{array}{llc}\text { Maize } & 15 \text { Inbreds and hybrids } & 28-85 \\ \text { Malze } & 20 \text { Races } & 48-59 \\ \text { Rire } & 3 \text { Varieties } & 12-30 \\ \text { Rice } & 50 \text { Varieties } & 34.5-62 \\ \text { Barley } & 7 \text { Varieties } & 17.7-21 \\ \text { Bean } & 5 \text { Varieties } & 13.7-18.5 \\ \text { Soybean } & 36 \text { Varleties } & 12-24 \\ \text { Soybean } & 9 \text { Varieties } & 18.7-23 \\ \text { Soybean } & 20 \text { Varieties } & 29-43 \\ \text { Gossypium } & 26 \text { Species } & 24-40 \\ \text { Tobacco } & 3 \text { Varieties } & 11-17\end{array}$


Table 3

Net Primary Productivity (NPP) and Energy Fixation of Major

Vegation Units of the World.

[Leith (2)]

\begin{tabular}{|c|c|c|c|c|c|c|c|}
\hline $\begin{array}{l}\text { Vegation } \\
\text { unit }\end{array}$ & $\left.0^{6} \stackrel{\mathrm{km}}{2}\right)^{\text {Area }}$ & $\begin{array}{c}\text { Range } \\
\left(\mathrm{kg} / \mathrm{m}^{2} \mathrm{a}\right)\end{array}$ & $\begin{array}{l}\text { Approx. } \\
\text { meean } \\
\left(\mathrm{kg} / \mathrm{m}^{2} \mathrm{a}\right)\end{array}$ & $\begin{array}{c}\text { Total } \\
\text { for area } \\
\left(10^{9} \mathrm{mt}\right)\end{array}$ & $\begin{array}{l}\text { Approx. } \\
\text { Com- } \\
\text { bustion } \\
\text { value } \\
(\mathrm{kcal} / \mathrm{g})\end{array}$ & $\begin{array}{l}\text { Mean } \\
\text { for } \mathrm{m}^{2} \\
\left(10^{6} \mathrm{cal} / \mathrm{m}^{2}\right)\end{array}$ & $\begin{array}{l}\text { Total for } \\
\text { Area } \\
\left(10^{18} \text { cal) }\right.\end{array}$ \\
\hline 1 & 2 & 3 & 4 & 5 & 6 & 7 & 8 \\
\hline $\begin{array}{l}\text { Forests } \\
\text { Tropical } \\
\text { rainforest }\end{array}$ & $\begin{array}{l}50 \\
17.0\end{array}$ & $1.0-3.5$ & 2.8 & $\begin{array}{l}81.6 \\
47.4\end{array}$ & 4.1 & 11.5 & $\begin{array}{l}368.6 \\
195.5\end{array}$ \\
\hline $\begin{array}{l}\text { Raingreen } \\
\text { forest }\end{array}$ & 7.5 & $1.6-2.5$ & 1.75 & 13.2 & 4.2 & 7.4 & 55.5 \\
\hline $\begin{array}{l}\text { Summergreen } \\
\text { forest }\end{array}$ & 7.0 & $0.4-2.5$ & 1.0 & 7.0 & 4.6. & 4.6 & 32.2 \\
\hline $\begin{array}{l}\text { Mediterianean } \\
\text { sclerophyll } \\
\text { forest (inclu- } \\
\text { sive chaparral) }\end{array}$ & 1.5 & $0.255-1.5$ & 0.8 & 1.2 & 4.9 & 3.9 & 5.9 \\
\hline $\begin{array}{c}\text { Warm temperate } \\
\text { mixed forest }\end{array}$ & 5.0 & $0.6-2.5$ & 1.0 & 5.0 & 4.8 & 4.7 & 23.5 \\
\hline Boreal forest & 12.0 & $0.3-1.2$ & 0.65 & 7.8 & 4.6 & $\therefore \quad 3.0$ & 36.0 \\
\hline Woodland & 7 & $0.2-1.0$ & 0.6 & 4.2 & 4.6 & 2.8 & 19.6 \\
\hline $\begin{array}{l}\text { Dwarf and Open } \\
\text { Scrub } \\
\text { Tundra }\end{array}$ & $\begin{array}{l}26 \\
0.8\end{array}$ & $0.06-1.3$ & 0.16 & $\begin{array}{l}2.6 \\
1.3\end{array}$ & 4.5 & 0.7 & $\begin{array}{r}11.0 \\
5.6\end{array}$ \\
\hline Desert scrub & 18.0 & $0.01-0.25$ & 0.06 & 1.3 & 4.5 & 0.3 & .5 .4 \\
\hline $\begin{array}{l}\text { Grassland } \\
\text { Tropical }\end{array}$ & 24 & & 0.8 & 19.2 & 40 & & 76.8 \\
\hline $\begin{array}{l}\text { grassland } \\
\text { (incl. grass- } \\
\text { dominated } \\
\text { Savannah) } \\
\text { Temperate } \\
\text { grassland }\end{array}$ & $\dot{y} . \dot{0}$ & $0.07-1.3$ & 0.8 & 7.2 & 4.0 & 3.2 & 28.8 \\
\hline Desert (extreme) & $\longdiv { 2 4 }$ & & & & & & 0.1 \\
\hline Dry desert & 8.5 & $0-0.01$ & 0.003 & - & 4.5 & -- & 0.1 \\
\hline Ice desert & 15.5 & $0-0.001$ & -- & -- & - & -- & -- \\
\hline Cultivated Land & 14 & $0.1-4.0$ & 0.65 & 9.1 & 4.1 & 2.7 & 37.8 \\
\hline
\end{tabular}


Table 3 (continued)

Net Primary Productivity (NPP) and Energy Fixation of Major

Vegation Units of the World.

[Leith (2)]

\begin{tabular}{|c|c|c|c|c|c|c|c|}
\hline $\begin{array}{l}\text { Vegation } \\
\text { unit }\end{array}$ & $\begin{array}{c}\text { Area } \\
\left.10^{6} \mathrm{~km}^{2}\right)\end{array}$ & $\begin{array}{c}\text { Range } \\
\left(\mathrm{kg} / \mathrm{m}^{2} \mathrm{a}\right)\end{array}$ & $\begin{array}{l}\text { Approx. } \\
\text { mean } \\
\left(\mathrm{kg} / \mathrm{m}^{2} \mathrm{a}\right)\end{array}$ & $\begin{array}{l}\text { Total } \\
\text { for area } \\
\left(10^{9} \mathrm{mt}\right)\end{array}$ & $\begin{array}{l}\text { Approx. } \\
\text { Com- } \\
\text { busliui } \\
\text { value } \\
(\mathrm{kcal} / \mathrm{g})\end{array}$ & $\begin{array}{l}\text { Mèain } \\
\text { for } \mathrm{m}^{2} \\
\left(10^{6} \mathrm{cal} / \mathrm{m}^{2}\right)\end{array}$ & $\begin{array}{l}\text { Total for } \\
\text { Area } \\
\left(10^{18} \text { cal }\right)\end{array}$ \\
\hline 1 & 2 & 3 & 4 & 5 & 6 & 7 & D \\
\hline $\begin{array}{l}\text { Fresh Water } \\
\text { Swamps and marsh } \\
\text { Lake and stream }\end{array}$ & $\begin{array}{l}4 \\
2.0 \\
2.0\end{array}$ & $\begin{array}{l}0.8-4.0 \\
0.1-1.5\end{array}$ & $\begin{array}{l}2.0 \\
0.5\end{array}$ & $\begin{array}{l}5.0 \\
4.0 \\
1.0\end{array}$ & $\begin{array}{l}4.2 \\
4.5\end{array}$ & $\begin{array}{l}8.4 \\
2.3\end{array}$ & $\begin{array}{r}21.4 \\
16.8 \\
4.6\end{array}$ \\
\hline $\begin{array}{l}\text { Total for } \\
\text { Continents }\end{array}$ & 149 & & & 121.7 & & & 535.3 \\
\hline $\begin{array}{l}\text { Open ocean } \\
\text { Upwelling zones } \\
\text { Continental } \\
\text { shelf } \\
\text { Algat beds } \\
\text { and reefe } \\
\text { Estuaries } \\
\text { Total Marine }\end{array}$ & $\begin{array}{c}332 \\
0.4 \\
26.6 \\
0.6 \\
1.4 \\
361\end{array}$ & $\begin{array}{l}0.002-0.4 \\
0.4-0.6 \\
0.2-0.6 \\
0.5-4.0 \\
0.5-4.0 \\
0.002-4.0\end{array}$ & $\begin{array}{l}0.13 \\
0.5 \\
0.36 \\
\\
2.0 \\
1.8 \\
0.161\end{array}$ & $\begin{array}{r}9.2 \\
1.2 \\
2.5 \\
55.0\end{array}$ & $\begin{array}{l}4.9 \\
4.9\end{array}$ & $\begin{array}{l}0.6 \\
2.5 \\
1.6 \\
9.0 \\
8.1\end{array}$ & $\begin{array}{r}199.2 \\
1.0 \\
43.1 \\
3.6 \\
11.3 \\
258.2\end{array}$ \\
\hline Overall'Total & 510 & & & 176.7 & & $\because$ & 793.5 \\
\hline
\end{tabular}


Table 4

Fraction of $\mathrm{CO}_{2}$ Emitted from Stack which is Dispersed Above the Annular Area at distances of 5 to $10 \mathrm{~km}$ from Power Plant

\begin{tabular}{llllllllll}
\hline $\mathrm{u}(\mathrm{m} / \mathrm{sec})$ & $0.5 \mathrm{hr}$ & $3 \mathrm{hr}$ & $10 \mathrm{hr}$ & $15 \mathrm{hr}$ & 1 day & 10 day & 50 days & 100 days & 1 year \\
\hline 4 & 0.360 & 0.841 & 0.949 & 0.966 & 0.979 & 0.998 & 1.000 & 1.000 & 1.000 \\
\hline 6 & 0.504 & 0.891 & 0.966 & 0.977 & 0.986 & 0.999 & 1.000 & 1.000 & 1.000 \\
\hline 10 & 0.661 & 0.933 & 0.979 & 0.986 & 0.991 & 1.000 & 1.000 & 1.000 & 1.000 \\
\hline
\end{tabular}

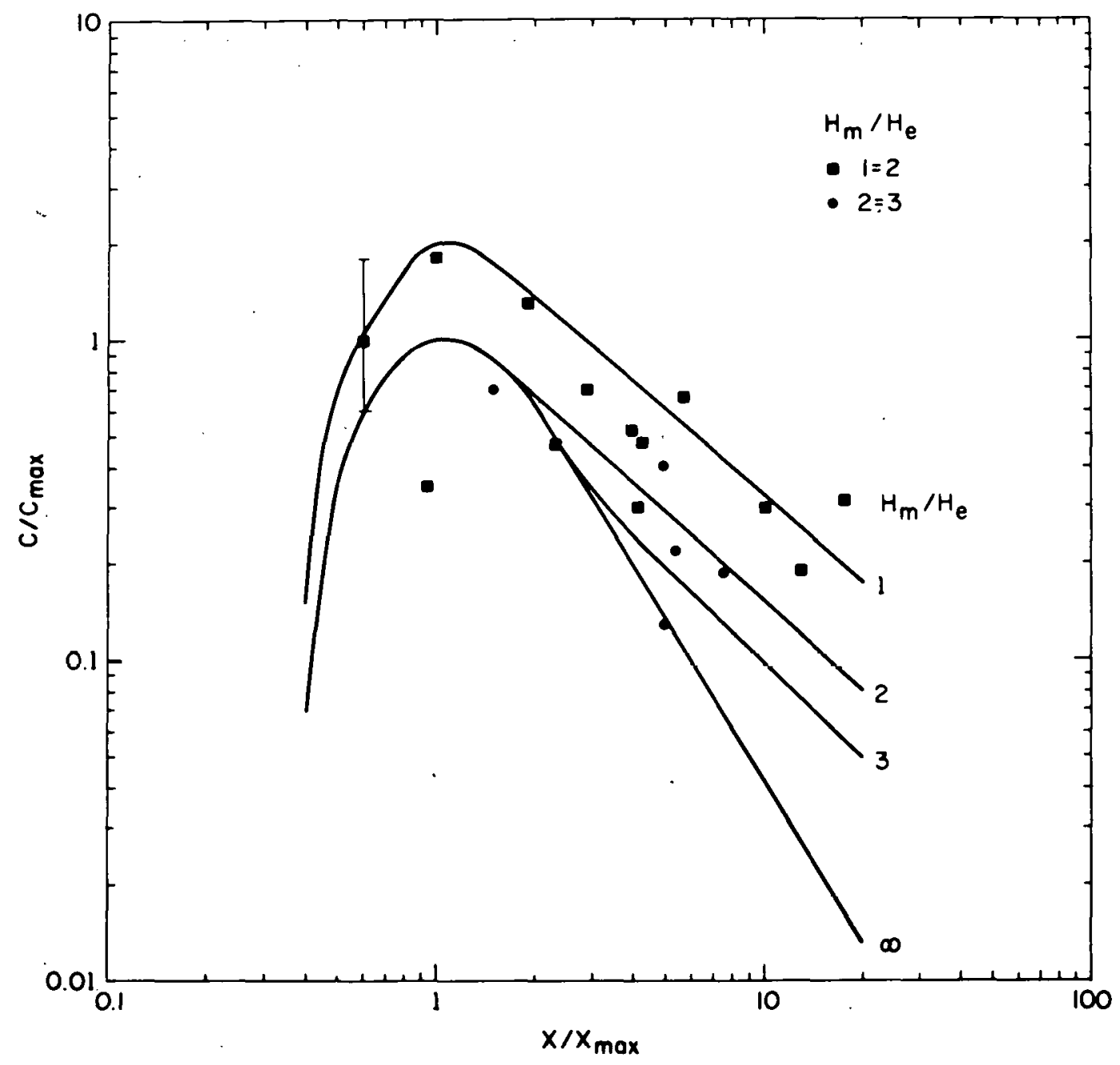

Figure 1. Measured ground-level $\mathrm{SO}_{2}$ concentration normalized ..... by $C_{\max }$ versus dimensionless downwind distance $\mathrm{x} / \mathrm{x}_{\max }^{\max }$ Gaussian plume model prediction.

$$
-19-
$$




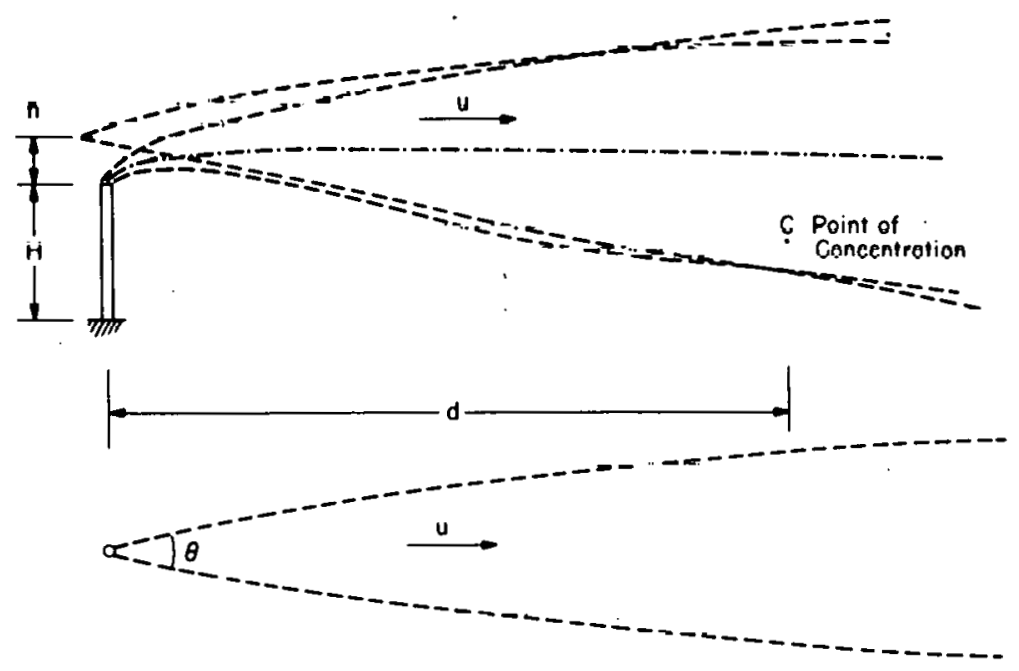

Figure 2. Schematic diagram of the gas plume diffusion... 


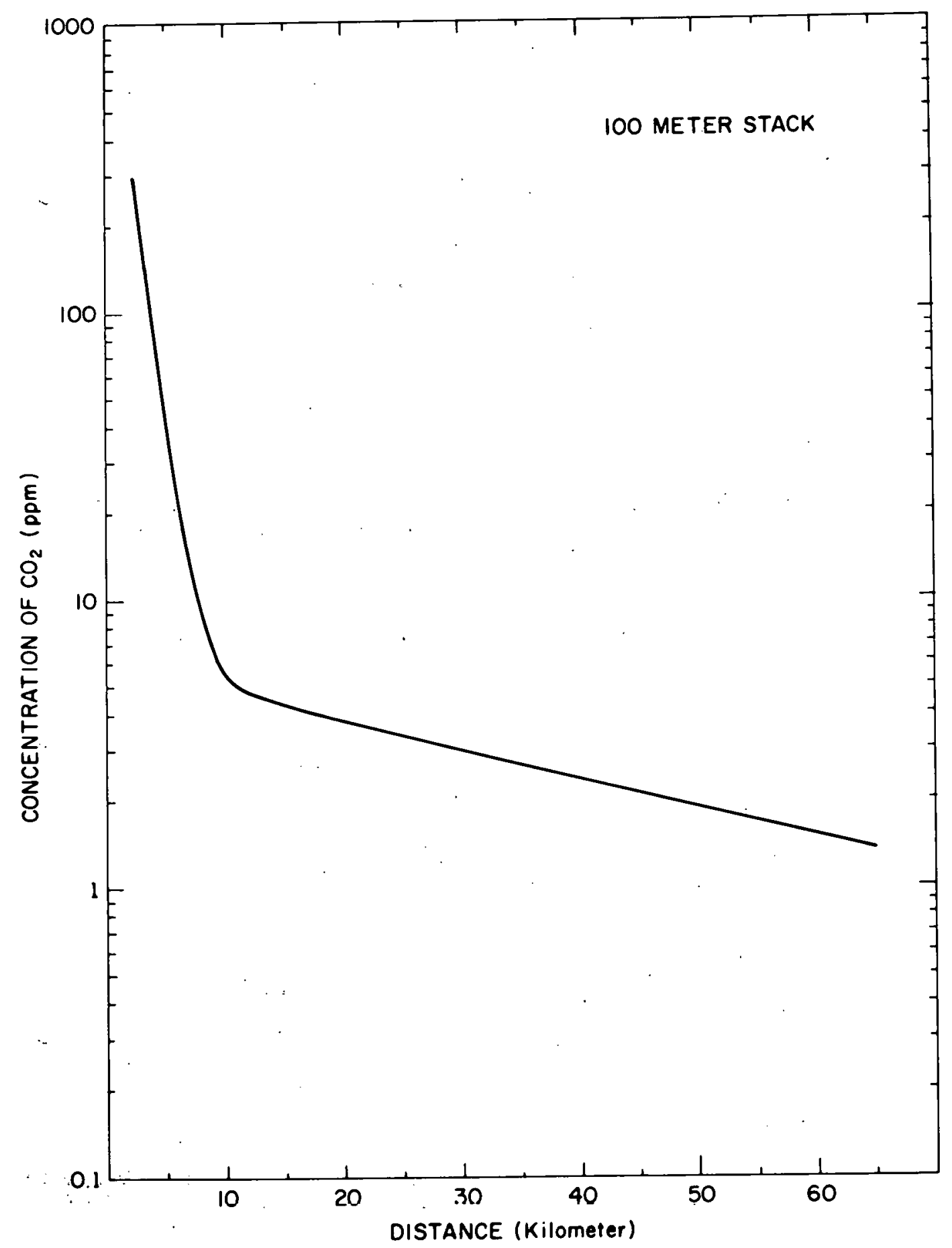

Figure 3. Concentration-distance for $\mathrm{CO}_{2}$ from $1000 \mathrm{MW}(\mathrm{e}) \ldots$ power plant. 


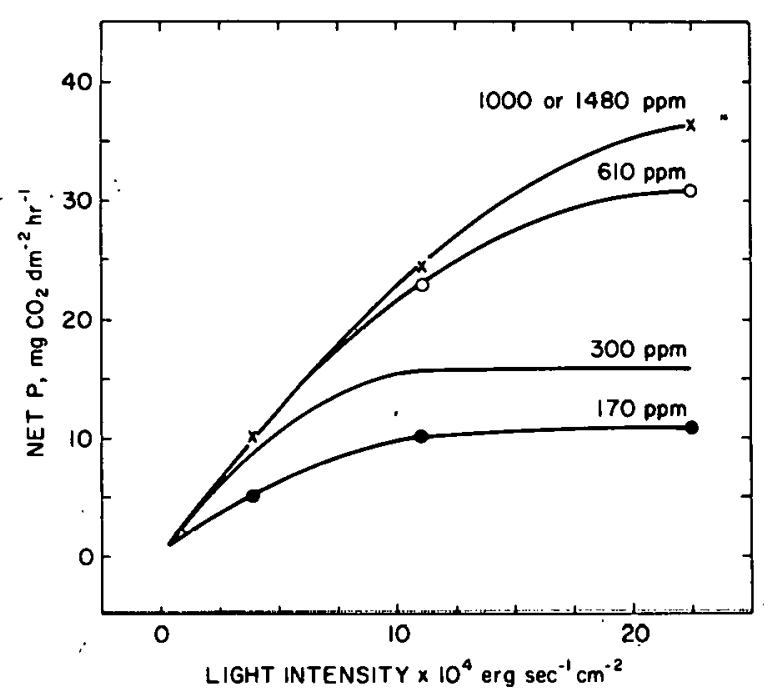

Figure 4. Net photosynthesis of intact young spinach plants in relation to light intensity at different $\mathrm{CO}_{2}$ concentrations (from Gaastra, 1959, Ref. [10]). Leaf temperature was 21 to $24^{\circ} \mathrm{C}$ and irradiation is given for the range from 400 to $700 \mathrm{~nm}$.

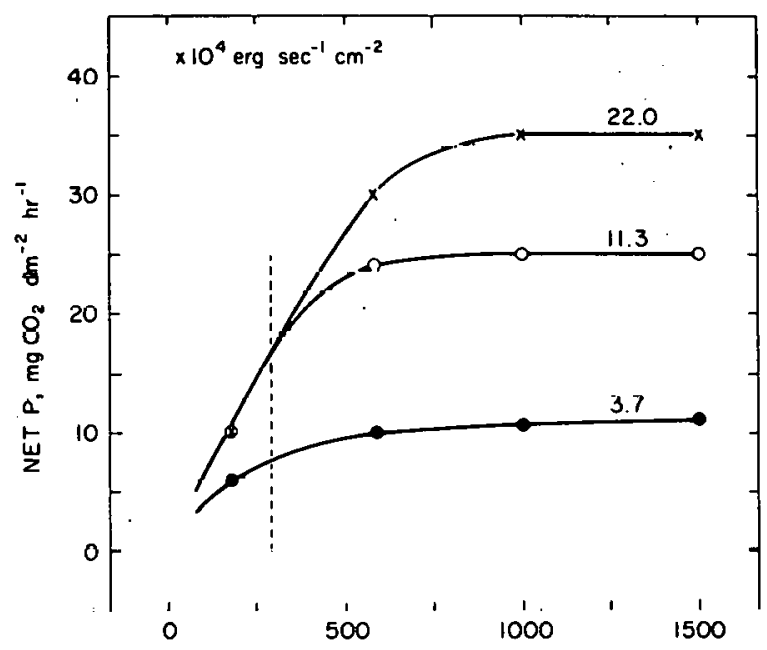

$\mathrm{CO}_{2}$ CONCENTRATION, PDM

Figure 5. Net photosynthesis of intact young spinach plants in relation to $\mathrm{CO}_{2}$ concentration at different light intensities (from Gaastra, 1959, Ref. [10]). Conditions as in Figure 4 with light intensities of $3.7,11.3$, and $22.0 \times 10^{4} \mathrm{erg} \mathrm{sec}^{-1} \mathrm{~cm}^{-2}$ as shown. The normal $\mathrm{CO}_{2}$ concentration of air is represented by the dashed 1 ine. 